\title{
Commercialization of Water Management Research Results - activities carried out as part of the Water Research to Market Project
}

\author{
Walczykiewicz Tomasz \\ Institute of Meteorology and Water Management, National Research Institute, Kraków Branch, Borowego Street 14, \\ 30-215 Kraków,Poland, e-mail: tomasz.walczykiewicz@imgw.pl \\ Loch-Dzido Alicja, Sobociński Zbigniew, Jato-Mrozik Aleksandra \\ GdańskWater Foundation, Rycerska Street9,80-882 Gdańsk,Poland,e-mail: alicja.ld@gfw.pl,zbigniew.s@gfw.pl,ola.m@gfw.pl
}

\begin{abstract}
An important element which completes all water management research is the practical implementation of the results and, if possible, further commercialisation, which is the subject of this paper. In practice, research results come in the form of specific copyright assets, protected under industrial property law or copyright law. In response to the need for solutions which would improve the process of commercializing research outcomes in water management is the Water Research to Market (WaterRtoM) project. The project is financed by the LIFE+ programme. The main goal of the project is to speed up the process of implementing research results in practice and to shorten the implementation period to 3-5 years by adding a step between research and the existing mechanisms for transferring technology.
\end{abstract}

Key words: maket, water, research, management, innovation

Submitted 25 March 2014, revised 17 April 2014, accepted 28 May 2014

\section{Introduction}

Water management is a research and business activity which is concerned with rational management and utilisation of surface and underground water. Water management is the part of the national economy, executed by competent authorities, which deals with the proper quantitative and qualitative control of water resources appropriate for the needs of the users and the natural environment. As a field of scientific study, water management deals with the modelling and optimization of qualitative and quantitative processes related to the control and use of water resources for current use and for planning purposes (Słota 1997). Contemporary determinant factors resulting from the principles of integrated water management put strict requirements as to the scope of the data and information necessary to use in methodological and technological solutions needed to fulfil the tasks of water management. Water policy should take into account research, analyses and expert opinions on hydrology, hydraulics, ecology, chemistry, soil science, engineering and economy, to evaluate the contemporary pressures on water resources in river basins and to define actions needed to achieve the environmental goals in the most economically effective manner. To achieve sustainable development, the relations between economic growth, environmental conservation and human health must be balanced in such a way, that the current needs can be satisfied without a negative impact on future generations. Water economy creates a system which integrates hydrological, meteorological and hydrogeological phenomena with the processes of water treatment and water supply, waste water treatment, hydraulic engineering, and the issues of planning, designing, exploitation and management of water resources. The main task of water management is to take actions to achieve the correct qualitative and quantitative characteristics of water resources.

The purpose of water resources management is to satisfy the needs of the public and the economy, to protect the body of water and the related environment, and in particular to:

- $\quad$ supply sufficient quantity and quality of water for the public,

- protect water resources from contamination and ina-ppropriate or excessive exploitation,

- maintain or improve the condition of water and waterdependent ecosystems,

- protect from flood and drought,

- ensure supplies of water for agriculture and industry,

- satisfy the needs related to tourism, sport and leisure,

- create the conditions for using waters for energy, transport and fishing purposes.

Contemporary problems of water management, given its integrated nature, should be resolved by multidisciplinary research teams, where hydrologists and hydraulic engineers should also include planners, economists, lawyers, managers and ecologists.

General research in water management is based on the knowledge of the processes occurring in the hydrosphere of technological processes. This way, it is possible to do the following:

- assess water resources,

- control and manage water resources,

- plan and prepare development programmes,

- maintain and regenerate natural resources,

- supply water, remove and treat waste water and manage drainage, 
- design, construct and operate the following:

- storage reservoirs,

- dams,

- bridges, culverts, canals,

- hydro power plants,

- water intakes,

- conduct crisis management during flood or drought.

Research related to water management can be divided into the following main groups:

- methodological work supporting water management processes,

- solutions for decision making support systems together with IT systems,

- new technology development.

An important element which completes all water management research is the practical implementation of the results and, if possible, further commercialisation, which is the subject of this paper.

\section{The background of the problem with commercia- lizing research results in water management}

The European Union puts special emphasis on research and development, as illustrated by the $7^{\text {th }}$ Framework Programme (FP7) which is the basic tool to achieve the strategic goal set in March 2000 by the European Council in Lisbon, i.e. to make the EU the most competitive and dynamic knowledge-based economy in the World, capable of sustainable economic growth with more and better jobs and greater social cohesion (Waltoś et al. 2012). The knowledge triangle composed of research, education and innovation is indispensable to achieve this goal. FP7 has the following objectives (European Commission 2007a):

- to support transnational cooperation in all areas of technological research and development,

- to increase the dynamism, creativity and excellence of European scientific research in pioneering fields of science,

- to reinforce the human potential in research and technology by providing better education and training, easier access to the research potential and infrastructure, higher esteem for the research profession and by encouraging researchers to become more mobile and pursue scientific careers,

- to intensify the dialogue between the world of science and the society in Europe in order to increase social trust in science,

- to support broad application of the results and dissemination of the knowledge acquired in the course of publicly financed research activities.

One important problem is the application of research, which, obviously, is not only financed by EU programmes, such as FP7 or structural funds, but also by national research programmes or businesses. The exploitation of the results of research was defined by Commission Regulation (EC) No 2659/2000 of 29 November 2000 (European Commission 2000a) which in that form remained in force until 31 December 2010.
In practice, research results come in the form of specific copyright assets, protected under industrial property law or copyright law. And so, the exploitation of the results of research and development requires prior acquisition of these rights. These are not the only limitations for the exploitation of research results. Another important problem, also pertinent for research outcomes in water management, is related to the existing barriers in the transfer of research results to practical exploitation.

Methodological projects can usually be implemented in practice only after being supplemented with application solutions. Frequently, their application is limited to local physiographic and morphologic conditions. Solutions for decision making support systems and IT systems, on the other hand, are restricted by existing hardware and software limitations. Research of new technologies often meets barriers in existing standards and regulations which might limit their application to a single country.

\section{The Water Research to Market Project}

In response to the need for solutions which would improve the process of commercializing research outcomes in water management is the Water Research to Market (WaterRtoM) project. The project is financed by the LIFE+ programme, contract LIFE09 ENV/FR/000593. The partners in this project are: International Office for Water (OIEau) from France, project coordinator, Gdańsk Water Foundation (GFW) from Poland, AMPHOS 21, a consulting office from Spain, and Fundatia Centrul de Formare si perfectionare Profesionala in Domeniul Apei (CFPPDA) from Romania. The project was initiated on 2 September 2010 and is scheduled to end on 31 August 2013. The goal of the project is to speed up the process of implementing research results in practice and to shorten the implementation period to 3-5 years by adding a step between research and the existing mechanisms for transferring technology to SMEs. The way to achieve it is by pro-actively searching for, assessing and promoting the research outputs, and in particular by:

- analysing research projects vs. market needs,

- permanent observation of research projects in water management and, as a result, selection of 20 to 30 of those and the assessment of the implementation of these projects,

- development of business undertakings for 8-12 research projects (outcomes of research projects) per year - the so-called innovation precursors,

- increasing the visibility of innovative solutions in water management and promoting precursors which are ready to take up innovative solutions,

- developing the idea of the project as a type of service for innovators after the project is concluded.

The activities of the project are mainly aimed at practitioners:

- basin and sub-basin authorities,

- urban planners and municipalities, 
- water users (agriculture, industries) and the "doers", i.e. the suppliers of new technologies,

- consultancies, operators (public or private) of water management facilities, as well as researchers and research funding bodies.

The general message of the project is the need for constant observation of the water management sector, and in particular:

- the entities which carry out research, in order to identify projects at European level (under EU Framework Programmes and national research programmes), to overview and select products which are interesting for water management, have discussions with their authors and keep a ranking of such products by their potentiality to be launched on the market,

- practical activities related to the constant review and analysis of any arising questions and the need for advanced tools which could help to fulfil water management tasks, including the participation in specialist forums organised by others.

The project provides for the participation of a supporting partner, in order to develop closer relations between the researchers and the practitioners who implement the research outputs. In consequence, a Liaison Committee was established to act in consultation capacity, composed of the representatives of the following:

- Water Supply and Sanitation Technology Platform,

- International Network of Basin Organizations,

- Water Technology Platform from Spain,

- Institute of Meteorology and Water Management National Research Institute from Poland,

- Romanian Water Association from Romania,
- Languedoc-Roussillon "Cluster EAU" (Pôle de compétitivité),

- Enterprise Europe Network.

To aid practitioners and researchers in the preparation of innovative projects, the WaterRtoM project will be using the cooperation and achievements of Enterprise Europe Network (EEN), a network of 70 local consortia, with approx. 600 partner organisations in more than 40 countries, promoting competitiveness and innovation at local level in Europe and beyond.

Activities undertaken under the project have been presented in the picture below:

\section{Methodology of research in the project}

The project uses strategies and tools which should allow the project to achieve its goal.

- Research Market Assessment Strategy (ReMAS)

This is a standardized method to assess the market potentiality of research outputs (tools, methods) and to assess the possible benefits of their implementations. For products assessed as "close to market," an individual market entry strategy is created (business ventures), in cooperation and close agreement with selected research teams. This strategy should be seen as a "roadmap" process defining the essential steps that need to be taken.

- E-Seminars

E-Seminars are part of the marketing strategy of WaterRtoM and their aim is to speed-up the transfer of research outputs to practitioners. Between brokerage events, national seminars and on-going exchange of knowledge via E-fairs, the project offers new ways

\begin{tabular}{|l|}
\hline $\begin{array}{l}\text { Action 1-Permanent } \\
\text { watching of the sector }\end{array}$ \\
\hline Action 1.1 \\
Establishing close \\
contacts with \\
stakeholders: OIEau \\
\hline Action 1.2 \\
Activities of the Liaison \\
Committee: OIEau \\
\hline Other Partners: \\
Amphos 21, GFW, \\
CFPPDA \\
\hline
\end{tabular}

\begin{tabular}{|c|}
\hline $\begin{array}{l}\text { Action } 2 \text { - Assessment } \\
\text { of potential benefits of } \\
\text { the created } \\
\text { tools/methods }\end{array}$ \\
\hline $\begin{array}{l}\text { Action 2.1 } \\
\text { Research to Market } \\
\text { Assessment Strategy: } \\
\text { OIEau }\end{array}$ \\
\hline $\begin{array}{l}\text { Action } 2.2 \\
\text { Ranking of outputs as } \\
\text { potential Precursors - } \\
\text { analyze: Amphos } 21\end{array}$ \\
\hline $\begin{array}{l}\text { Other Partners: GFW, } \\
\text { CFPPdA }\end{array}$ \\
\hline
\end{tabular}

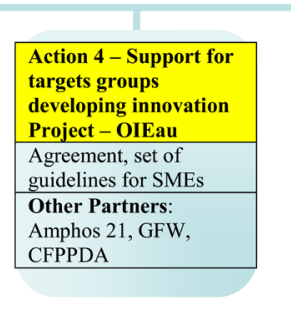

Action 5 Sustainability of WaterRtoM as a service after project completion - OIEau Business plan Other Partners: Amphos 21, GFW CFPPDA
Action 6 Dissemination - OIEau Documents to disseminate, $\mathrm{e}-$ infrastructure, laymen's report Other Partners: Amphos 21, GFW, CFPPDA

Fig. 1. Activities under the WaterRtoM project and the responsible bodies 
to participate in active discussions during two-hour on-line conferences, each focussed on a topic promoted by project partners. The goals of E-seminars are to actively inform about and promote research outputs, to stimulate interest and to attract potential practitioners who are ready to implement them. E-Seminars are conducted on-line via Internet, using software which offers high quality video, audio and graphics. Thanks to their format, E-Seminars are available anytime, anywhere, they eliminate travel expenses and other added costs of direct training participation.

- E-Fair facility

E-Fair is a search engine which can be used to find sets of research outputs selected by project experts which already exist, but are not on the market yet. A wide range of products have been identified, which may interest those who are looking for particular research outputs. The search engine has been designed with an emphasis on the precision of search criteria.

\section{Results until present date}

The first months of the project were devoted to defining such notions as Product, Market Needs or Risk for Innovation, so we can smoothly go to phase two, i.e. designing the ReMAS tool and other tools needed to go ahead with the project (i.e. market research, E-Fairs, E-Seminars etc.).

The facility was released, which supports the search for projects related to the water sector and various directives:

- Directive 2000/60/EC of the European Parliament and of the Council of 23 October 2000 establishing a framework for Community action in the field of water policy - Water Framework Directive (European Commission 2000),

- Directive 2007/60/EC of the European Parliament and of the Council of 23 October 2007 on the assessment and management of flood risks (Text with EEA relevance) - Flood Directive (European Commission 2007),

- Council Directive 98/83/EC of 3 November 1998 on the quality of water intended for human consumption (European Commission 1998),

- Directive 2006/7/EC of the European Parliament and of the Council of 15 February 2006 concerning the management of bathing water quality and repealing Directive 76/160/EEC (European Commission 2006),

- Council Directive 91/676/EEC of 12 December 1991 concerning the protection of waters against pollution caused by nitrates from agricultural sources (European Commission 1991a),

- Directive 2006/118/EC of the European Parliament and of the Council of 12 December 2006 on the protection of groundwater against pollution and deterioration (European Commission 2006a),

- Council Directive 86/278/EEC of 12 June 1986 on the protection of the environment, and in particular of the soil, when sewage sludge is used in agriculture (European Commission 1986),
- Council Directive 91/271/EEC of 21 May 1991 concerning urban waste-water treatment (European Commission 1991).

A extended website for the project was created at www. waterrtom.eu, maintained in four languages (English, French, Polish and Romanian) and regularly updated. The strategy for outputs dissemination also includes a quarterly newsletter which describes current and planned activities.

By March 2012, the project partners selected 144 research projects carried out as part of EU programmes, national research programmes or funded by own resources of the research teams. All these projects went through a preliminary assessment using ReMAS e-tool. As a result, 33 projects were chosen, with outputs that were assessed as most advanced and closest to market. The projects underwent detailed analysis with the use of the ReMAS e-tool in order to find such research outputs which are innovative and ready for practical implementation. As a result, 13 projects were chosen as the so-called innovation precursors; thus, the research outputs of these projects are treated as products for which individual implementation strategies are developed. This procedure for finding innovation precursors will be used throughout the project. It is assumed that by the end of the project between 24 and 30 such innovative solutions for water management will be identified.

Using this procedure, detailed databases have been created of the following:

- projects and products which meet the WaterRtoM project guidelines,

- potential practitioners who could use the promoted products,

- project authors willing to join WaterRtoM.

Given the specificity of local conditions, each of the WaterRtoM partners developed their own strategy to disseminate information about project results. Generally, the partners arranged seminars in their home countries, focussing on specific subjects, and online E-Seminars. Another expected activity was the participation in a variety of industry specific events, be it local, national or international. So far, the results of the work carried out in the project were presented at the following events:

- Euro-INBO 2011 (27-30 September 2011, Porto, Portugal),

- Iberian Congress on Groundwater: Management challenges for the 21st Century (14-17 September 2011, Saragossa, Spain),

- International Water Week 2011 (29 October - 4 November 2011, Amsterdam, the Netherlands),

- SMAGUA (6-9 March 2012, Saragossa, Spain),

- WOD-KAN 2012 (22-24 May 2012, Bydgoszcz, Poland),

- GREEN WEEK 2012 (22-25 May 2012, Brussels, Belgium),

- EXPOAPA (11-13 June 2012, Bucharest, Romania),

- CONAMA (26-30 November 2012, Madrid, Spain),

- POLEKO 2012 (22-25 November 2012, Poznań, Poland),

- POLlUTEC 2012 (27-30 November 2012, Lyon, France). 


\section{Summary and conclusions}

EU activities for environmental protection focus on improving the quality of life of every citizen and put an emphasis on such methods which become more effective through mutual cooperation. This policy, based on the principle of sustainable development, protects of the Earth's heritage, so that the next generations receive a sustainable environment. This principle is true for any sphere of activity and it is all about finding the delicate balance between environmental protection, economic progress and social development, in order to ensure the well-being of future generations in all parts of the world. The preamble Water Framework Directive (European Commission 2000) emphasises that »Water is not a commercial product like any other but, rather, a heritage which must be protected, defended and treated as such «. We need to deepen the current knowledge of hydrological, hydrogeological, hydrochemical and environmental mechanisms which govern the systems of groundwater and surface water, and the knowledge of modern technologies in water/sewage management. In the times of climate change, there is a need to improve the tools which reduce the sensitivity of water management to such changes, including the rationalization of water management systems. Research outputs are used to give direction to modernization projects. The direct beneficiaries of water management research include authorities at central, regional and local level, especially those which are responsible for: public safety, spatial planning, natural resource management, agricultural development, power industry, land, sea, inland water, and air transport, municipal services and, indirectly, businesses operating in these sectors.

An example of the attempts to commercialize research outputs in water management is provided by the KLIMAT project (The effects of climate change on the environment, the economy and the society - changes, their effects and the ways to mitigate them, conclusions for science, engineering and economic planning) carried out at the Institute of Meteorology and Water Management - National Research Institute in Poland (KLIMAT project) in the years 2008-2012. Some of the major outputs of the project in the area of water management are:

- the development of grid layers which show the hypothetical percentage changes in the unit effluence in the years 2011-2030, compared to 1971-1990 for 3 climate change scenarios: A2, AlB, B1 for the territory of Poland, and the methodology of adopting/ applying them to any area,

- the analysis of the trends in the changes in water consumption in selected sectors of the processing industry,

- the development of numerical layers of soils, together with their characteristics, and the numeric layers of the forms of land use, together with the data on agricultural crop structure in the pilot sub-basins of the Orla and the Sanna rivers,
- the development of methodologies for preparing water requirement forecasts based on socio-economic development scenarios,

- the development of water resource protection strategy for surface and groundwater, to satisfy the basic need for water of the population, agriculture and industry, based on the expected socio-economic development. The potential users of the results can be government Ministries, such as: Environment, Agriculture, or Regional Development, as well as local authorities, universities, insurance companies, agricultural consultancy centres, rural municipalities with intensive agriculture including municipalities in the Orla and the Sanna sub-basins, as well as KZGW (National Water Management Authority) and RZGWs (Regional Water Management Authorities). The target users of the applied methodologies will be the administrators of watercourses and hydrotechnical structures, the teams at IMGW-PIB (Institute of Meteorology and Water Management - National Research Institute) which are responsible for various tasks related to hydromorphological monitoring, planners and designers of hydrotechnical development of rivers, and streams, and the users of water. The strategy developed during the project may become a tool supporting development plans and programmes at all levels of government administration.

Project outcome sustainability in the years following its completion was ensured by the following:

- implementation of the outcomes in subsequent planning cycles under Water Framework Directive (European Commission 2000) and Flood Directive (European Commission 2007) in response to procurements by water management agencies,

- delivering expert opinions, analyses and water/economic balance sheets with the use of the project outcomes,

- publishing a handbook for companies, defining the necessary technical procedures recommended for activities compensating for environmental losses caused by hydrotechnical construction projects,

- publishing a guidebook on how climate change may put protected areas under threat,

- assessing the effect of hydrotechnical construction projects on flowing waters.

After project completion, offers for potential users were prepared.

The example of the KLIMAT project, with its broad scope of research subjects and the wide range of potential beneficiaries, demonstrates the need to look for solutions which will work in current legal environment and will speed up the transfer of research outcomes to market in water management. The "Water Research to Market" creates the foundations for such speed-up.

\section{Bibliography}

European Commission, 1986, Council Directive 86/278/EEC of 12 June 1986 on the protection of the environment, and in 
particular of the soil, when sewage sludge is used in agriculture, Official Journal, L 181, 04/07/1986, p. 0006-0012

European Commission, 1991, Council Directive 91/271/EEC of 21 May 1991 concerning urban waste-water treatment, Official Journal, L 135, 30/05/1991, p. 0040-0052

European Commission, 1991a, Council Directive 91/676/EEC of 12 December 1991 concerning the protection of waters against pollution caused by nitrates from agricultural sources, Official Journal, L 375, 31/12/1991, p. 0001-0008

European Commission, 1998, Council Directive 98/83/EC of 3 November 1998 on the quality of water intended for human consumption, Official Journal, L 330, 05/12/1998, p. 00320054

European Commission, 2000, Directive 2000/60/EC of the European Parliament and of the Council of 23 October 2000 establishing a framework for Community action in the field of water policy, Official Journal, L 327, 22/12/2000, p. 00010073

European Commission, 2000a, Commission Regulation (EC) No 2659/2000 of 29 November 2000 on the application of Article 81(3) of the Treaty to categories of research and development agreements, Official Journal, L 304, 05/12/2000, p. 0007-0012

European Commission, 2006, Directive 2006/7/EC of the European Parliament and of the Council of 15 February 2006 concerning the management of bathing water quality and repealing Directive 76/160/EEC, Official Journal, L 064, 4/03/2006, p. 0037-0051

European Commission, 2006a, Directive 2006/118/EC of the European Parliament and of the Council of 12 December 2006 on the protection of groundwater against pollution and deterioration, Official Journal, L 372, 27/12/2006, p. 0019-0031

European Commission, 2007, Directive 2007/60/EC of the European Parliament and of the Council of 23 October 2007 on the assessment and management of flood risks (Text with EEA relevance), Official Journal, L 288, 06/11/2007, p. 0027-0034

European Commission, 2007a, FP7 in Brief. How to get involved in the EU 7th Framework Programme for Research, Office for Official Publications of the European Communities, Luxembourg

KLIMAT project The effects of climate change on the environment, the economy and the society - changes, their effects and the ways to mitigate them, conclusions for science, engineering and economic planning) - http://klimat.imgw.pl

Słota H., 1997, Zarządzanie systemami gospodarki wodnej, IMGW, Warszawa, pp. 130

Waltoś S., Rozmus A., 2012, Kariera naukowa w Polsce. Warunki prawne, społeczne i ekonomiczne, Wolters-Kluwer-LEX, Warszawa, pp. 294. 